\title{
Mental Health and Primary Care: Contributing to Mental Health System Transformation in Canada
}

[French translation: Santé mentale et soins de première ligne : facteurs contribuant à la transformation du système de santé mentale au Canada]

\author{
Nick Kates \\ McMaster University
}

[La version française suit.]

\begin{abstract}
For 20 years mental health and primary care providers across Canada have been working collaboratively together to improve access to care, provider skills, and patient experience. The new strategic plan of the Mental Health Commission of Canada (MHCC) offers many opportunities for collaborative care to play a role in the transformation of Canada's mental health systems. To assist the plan, this paper presents principles underlying successful projects and ways that mental health and primary care services can work together more collaboratively, including integrating mental health providers in primary care. It integrates these concepts into a Canadian Model for Collaborative Mental Health Care that can guide future expansion of these approaches, and suggests ways in which better collaboration can address wider issues facing all of Canada's health care systems.
\end{abstract}

Keywords: collaborative care, primary care, integrated care

\section{RÉSUMÉ}

Depuis 20 ans, les prestataires de soins en santé mentale et de soins de santé de première ligne de partout au Canada travaillent en étroite collaboration pour améliorer l'accès aux soins, les compétences des prestataires et l'expérience des patients et patientes. Le nouveau plan stratégique de la Commission de la santé mentale du Canada (CSMC) ouvre la voie à un éventail de possibilités pour que les soins de santé collaboratifs puissent jouer un rôle dans la transformation des systèmes de santé mentale au Canada. Pour

Nick Kates, Department of Psychiatry and Behavioural Neurosciences, Michael G. DeGroote School of Medicine, McMaster University, Hamilton, Ontario.

There was no funding support for any aspect of the preparation of this paper.

Correspondence concerning this article should be addressed to Nick Kates, Chair, Department of Psychiatry, McMaster University, Room B358, St. Joseph's Healthcare W 5th. Campus, 100 W 5th Street, Hamilton, ON, L9C 0E3. Email: nkates@mcmaster.ca 
aider à formuler le plan, le présent document présente les principes qui sous-tendent les projets fructueux et explique comment il est possible pour les services de soins en santé mentale et les services de première ligne de collaborer davantage ensemble, par la voie, entre autres, de l'intégration des prestataires de soins en santé mentale au sein même des services de première ligne. Il intègre ces concepts dans un Modèle canadien de soins collaboratifs en santé mentale susceptible d'orienter le développement futur de ces approches, et propose des moyens pour qu'une collaboration plus soutenue puisse permettre de régler les problèmes plus vastes auxquels sont aujourd'hui confrontés tous les systèmes de santé du Canada.

Mots clés : soins de santé collaboratifs, soins de santé de première ligne, soins de santé intégrés

The family physician or primary care practice is the first point of contact with the health care system for many Canadians with mental health and addiction problems. Primary care is the place where the majority of mental health care is delivered (Thota et al., 2012), including care for individuals with complex medical conditions and co-existing mental health problems, often without the involvement of a specialized mental health care provider.

The prevalence of patients with mental health problems in primary care is high, according to the Agency for Healthcare Research and Quality (2010), but not all family physicians have the training, resources, confidence, or organizational supports to detect and manage their patients' needs, and they often face challenges in their relationship with mental health services when seeking help. These can include problems with access to services and lengthy waiting times (Craven \& Bland, 2006), inconsistent intake criteria, poor communication, and a lack of support for managing complex mental health problems in their office. This leads to fragmented, discontinuous, and poorly coordinated care and unnecessary obstacles for their patients when trying to access or move between services they need.

At the same time, the majority of individuals with mental health and addiction problems receive no treatment over the course of a year (Wang et al., 2005), and their problems often go undetected. Over 80\% of the population will see their family physician during a year (Lesage, Goering, \& Lin, 1997), however, including many individuals with co-existing physical health problems / chronic conditions and mental health problems, usually depression or anxiety (Katon et al., 2010). This suggests the family physician's office may be the logical, and sometimes the only, place for identifying these problems, initiating treatment, and coordinating referrals to secondary or tertiary services.

Although these problems are not unique to Canada - indeed most countries face similar issues - Canada has made substantial progress over the last 20 years in addressing these issues and providing a framework to foster the development of better collaboration, with the goal of ensuring each person receives the right care from the right provider as rapidly as possible, in the most convenient location, and with the minimum of obstacles (Kates, Mazowita, et al., 2011)

This paper reviews the major factors that have contributed to or influenced these changes, identifies the key components of successful Canadian collaborative initiatives, and outlines ways in which collaborative care can address challenges facing every health and mental health care system in Canada. The importance of better collaboration between these two sectors was recognized by the Mental Health Commission of Canada in their initial strategic plan, and remains an important part of their emerging agenda. 
To assist with translating policy into practice, this paper outlines principles, components of successful programs, and directions to follow that can be adapted to any community. Indeed, one of the strengths of Collaborative Mental Health Care (CMHC) in Canada has been the ability to adapt these principles to meet the differing needs of specific communities and populations. At the same time, there is a need for greater standardization and the routine adoption of activities that have been demonstrated to be effective in Canada or elsewhere.

\section{THE EVOLUTION OF COLLABORATIVE MENTAL HEALTH CARE IN CANADA}

Although disconnected initiatives aimed at improving collaboration between mental health and primary care services took place historically through Centres Local de Services Communautaires (CLSCs) in Quebec, health service organizations in Ontario, and community health centres across Canada, or by enhancing the training of family medicine residents in managing mental health problems, CMHC really came to life in 1997 when the Canadian Psychiatric Association and the College of Family Physicians of Canada published a joint position paper to promote collaboration between the two sectors (Kates et al., 1997).

The 1997 paper made the case for psychiatrists, other mental health care providers, and family physicians to work together more closely, and outlined principles to guide collaborative care (or shared care as it was then referred to). The paper also highlighted examples of ways to improve collaboration, emphasized the importance of training future practitioners in these models, and outlined the benefits of collaboration for underserved communities and populations.

This initiated what has been a remarkable change in the landscape. (Kates, 2008). Mental health and primary care services and providers have been rethinking how they work together and the roles each can play in a better integrated and coordinated system. A wide variety of projects that aim to improve collaboration and build new partnerships have emerged across the country. These have taken advantage of broader transformations in primary care systems over the last 15 years, such as a focus on the role of primary care as the foundation of local and provincial health systems, the integration of a wide variety of health care professionals within primary care settings to support comprehensive inter-professional team-based care, and a greater emphasis on prevention and the management of chronic conditions. These new directions are reflected in the position paper A Vision for Canada: Family Practice: The Patient's Medical Home by the College of Family Physicians of Canada (2011).

Within provincial ministries of health, primary care and mental health planners are working more closely together and developing and funding integrated projects, either as single entities or as part of a more comprehensive provincial strategy. These include the Centres de Santé et de Services Sociaux (CSSS) in Quebec, Family Health Teams (FHTs) in Ontario, Primary Care Networks in Alberta, and the Practice Support Program in British Columbia.

A major boost for collaborative care was provided by two federal primary care innovation funds in the early 2000s. These funds supported many provincial demonstration projects with a mental health focus and one major national initiative, the Canadian Collaborative Mental Health Initiative (CCMHI). This project brought together 12 national organizations representing providers, consumers, and family members, and by 2006 the CCHMI had laid down a conceptual framework for collaborative care, completed a comprehensive 
review of the existing literature, and developed web-based toolkits to guide the implementation of CMHC in general settings and for specific populations (Gagné, Dudgeon, \& Kates, 2006). This initiative also fostered a broadening of collaborative partnerships to include a wider range of health professionals, including nurses, psychologists, social workers, pharmacists, and occupational therapists, as well as, importantly, consumers and families.

Other changes have supported the growth of collaborative care. Many provinces have introduced changes in their billing tariffs to support telephone consultations between psychiatrists and family physicians. The Canadian Medical Protective Association has acknowledged that informal case discussions-so-called corridor or curbside consultations - are an accepted and integral part of practice and should be encouraged (a reversal of its previous position) as long as accepted standards of care for each discipline are followed.

In 2010, the Royal College of Physicians and Surgeons of Canada made training in collaborative care a routine requirement for all psychiatry residents, while the College of Family Physicians of Canada has introduced a new "Triple C" (comprehensive education, continuity of education, and centred in family medicine) curriculum that emphasizes the role of the family physician in providing mental health care.

The Canadian Medical Association also continues to promote patient-centred collaborative care between specialists and family physicians, and in 2014, in partnership with the Canadian Psychiatric Association, the Canadian College of Family Physicians and the Mental Health Commission of Canada produced a paper outlining mental health core competencies that all physicians, in all specialties, should acquire during their training (Mental Health Core Competencies Steering Committee, 2014).

These activities and changes led the CPA and CFPC to review and revise the original position paper in 2011 (Kates, Mazowita, et al., 2011). While reaffirming the importance of better collaboration and its underlying principles, the paper summarized the evidence regarding the success of the collaboration model, noted the key components of effective collaboration, highlighted examples of successful models in Canada and elsewhere, and presented a framework for an integrated mental health and primary care system with suggestions for ways to improve collaboration. The position paper also pointed out the importance of additional and broader system changes to support collaborative care and started to reframe collaborative care within the domains of the quality agenda.

Building on this solid foundation and learning from the experiences of the wide range of successful partnerships that have been established over the last 20 years in Canada and other locations, this paper pulls together the core components of successful collaborate initiatives in Canada to present a Canadian model for collaborative care. It includes a common definition of collaborative mental health care and vision for an integrated mental health and primary care system. It outlines the four major approaches to improving collaboration that have emerged across Canada; the principles that should underlie collaborative projects; the components, functions, and benefits of successful programs; broader system supports required to support and promote collaborative care; and opportunities for CMHC to address wider challenges facing Canada's health care systems. 


\section{A Canadian Definition of Collaborative Mental Health Care}

A variety of different terms are used, often interchangeably, to describe collaborative partnerships, including:

- $\quad$ shared care, which describes collaboration between two providers, usually physicians

- integrated care - the term commonly used in the United States and which in Canada; refers to the integration of mental health services within primary care settings;

- collaborative care, the phrase most commonly used in Canada today, which describes models and activities in which mental health and primary care providers, usually working in teams, find new ways to work together more closely and productively, including integrated care.

In a recent position paper, colleagues and I proposed the following definition:

Collaborative care is used as an overarching term to describe the process whereby primary care and mental health providers share resources, expertise, knowledge and decision-making to ensure that primary care populations receive person centred, effective and cost effective care from the right provider in the most convenient location and in the most timely and well coordinated manner. (Kates et al., 2018)

\section{A VISION FOR THE ROLES OF PRIMARY CARE AND MENTAL HEALTH SERVICES IN AN INTEGRATED SYSTEM}

Better collaboration offers opportunities to expand and strengthen the services that primary care can offer. To take full advantage of this, there is a need to rethink the role that primary care could play as part of an integrated primary care / mental health network of services and the different ways for mental health services to better support these new roles.

\section{New Roles for Primary Care}

As most primary care practices look after a discrete population, have an ongoing relationship with their patients, and are often the first point of contact for someone with mental health or addictions problems, primary care is well positioned to deliver services that are beyond the scope of traditional mental health services, if appropriate support is available. These include:

- preventive interventions and mental health promotion;

- the earlier detection of mental health and addictions problems;

- $\quad$ earlier initiation of treatment;

- monitoring after an episode of care, or after discharge from a mental health services, to prevent further relapses;

- integrating physical and emotional care, especially for individuals with complex conditions;

- family support;

- coordinating care; and

- system coordination and navigation. 
If primary care is to assume a broader role in mental health care, however, mental health services need to make adjustments to support these roles. These include:

- access to rapid consultation when required, even if there may still be a wait for ongoing treatment;

- follow-up of selected individuals who can't be managed in primary care, for example, individuals requiring rehabilitation programs or more specialized treatment;

- delivery of programs that are beyond the scope of primary care (i.e., rehabilitation programs or some more specialized treatments);

- advice around community management and resources;

- ongoing support for primary care providers in person, by phone, by email, or using web-based applications;

- rapid access to reassessment of individuals if they begin to decompensate; and

- training and capacity building with primary care providers.

\section{Principles to Guide Collaborative Care}

Whatever the setting or focus, successful projects invariably share a number of common features. If an initiative is to thrive it needs to be based upon principles that guide effective collaborative partnerships and are adapted to meet local needs, rather than just trying to transplant a model developed in another location. Central to every successful collaborative project has been the development of personal contacts between providers from different sectors, with regular, effective, and timely two-way communication.

Other principles include those that should guide the relationship between different providers and those to guide the relationship between different services or systems.

\section{Between individual providers.}

- mutual respect

- mutual support

- recognition of each others' strengths and limitations

- the sharing of responsibility for care according to respective skills, demands and resources

- coordination of care and care plans

\section{Between services.}

- willingness on the part of all partners to make adjustments

- agreement on the goals of an initiative

- adapting models to respond to local needs and demands

- centring the needs of the patient and their family

- regular monitoring, evaluation, and - if necessary - readjustment of the goals and activities

- joint planning from the outset 


\section{Approaches to Improving Collaboration}

Canadian programs have generally adopted one of four approaches to improving collaboration in mental health services: (a) mental health services working more closely with local family physicians; (b) initiatives aimed at increasing the skills and comfort of primary care providers in managing mental health problems in their practice (building capacity); (c) the integration of primary care providers within mental health programs; and (d) the integration of mental health services within primary care settings.

Working more closely with physicians. There are many things any mental health service can do to work more collaboratively, although the range of options increases when there is closer proximity and regular personal contact. Many of the ideas proposed here can be introduced at little or no cost by any mental health service. They include improving communication between service providers, better and more timely consultation, and better coordination of care.

A simple first step is for a mental health service is to ask local family physicians through a survey, discussions at existing meetings, or small focus groups how collaboration is working and to seek their advice on strengthening the partnership and better meeting the needs of physicians.

The development of protocols for contacting the family physician when someone is admitted to a service, when starting discharge planning or changing medications, and when making referrals to another service, help to standardize the adoption of best practices. This can be assisted by the simplification of intake procedures and inclusion or exclusion criteria, which often make little sense to the referral source.

The rapid transmission of reports with relevant and practical information and a clear treatment plan is always helpful. Calling the family physician — or the patient — routinely a week and a month after discharge to find out whether connections have been made can facilitate the implementation of the plan.

While traditional face-to-face consultation with a patient remains a central activity for a mental health service, there are other ways in which a family physician can access helpful advice about a person they are seeing, such as telephone consultations and, increasingly, email communication (e-consults). If patient identification information is not exchanged, questions can be asked and responded to easily and quickly.

To improve access to care, some mental health services with a lengthy wait for ongoing service (greater than 3 months) have set up a rapid consultation service to provide a quick consultation and initial treatment / management advice to a family physician, with the patient going back on the waiting list for ongoing care, if required. The mental health team can continue to provide telephone advice or support to the family physician until such time as the patient is picked up or the problem has resolved.

Individuals with mental health problems are often disadvantaged by the fragmentation of mental health services, and may face challenges in moving smoothly from one service or sector to another. Clarity with respect to who is responsible for each part of the care plan can reduce these challenges, as can flexibility in intake or admission criteria.

The development of an individualized treatment plan that is brief, focused, and practical is crucial. Ideally the person should be given a copy of the plan that they can take to all appointments, making sure everyone involved knows what the plan is. Coordination can also be improved by the creation of a discharge planning checklist with simple steps that all providers in a service would routinely follow. A mental health 
provider can also arrange for the last appointment before discharge to take place in the office of the family physician, to ensure everyone knows the plan and who is responsible for what.

Building the capacity and capability of primary care providers. These initiatives aim to increase the skills and comfort of family physicians and other primary care providers in recognizing and managing mental health problems in primary care, thereby expanding the range of effective services being delivered in primary care.

Continuing education workshops and presentations can be effective but need to be relatively brief, case- or problem-based, interactive, and relevant to the realities and demands of primary care, address topics chosen by family physicians, and include family physicians, as well as specialists, as presenters. They also need to be followed up afterwards, rather than being just a "one-off" that is easily forgotten.

Alternatively, mental health specialists can visit the primary care setting for educational activities that adhere to the principles enunciated above but also open up new opportunities for learning. Options include case or problem-based presentations on a specific topic, and discussing or reviewing cases the family physician is seeing. Any case seen in consultation provides opportunities for educational input on issues the case raises.

Information can also be provided on practical tools such as screening instruments, management guidelines, resources for patients, community programs, and so on, all of which can be contained within a single accessible web location, or integrated within an electronic medical record, to enhance different aspects of the delivery of mental health care. It can also be helpful to give primary care providers links to readily usable and downloadable online materials, such as self-management skills for someone who is depressed.

Some more comprehensive programs, such as British Columbia's Practice Support Program (PSP), have integrated all of these components in their Adult Mental Health (AMH) module, a training and support program for physicians and their medical office assistants. The online resources include screening and assessment tools that present an organized, guideline-based system for physicians and incorporate self-management processes to empower patients to be active partners in their mental health treatment. This program has also developed a module for children and adolescents, and has been successfully introduced in Nova Scotia and Yukon.

Integrating primary care providers within mental health services. Individuals with severe and persistent mental illnesses have an increased risk of developing chronic conditions such as diabetes, vascular disease, and respiratory problems but, for a variety of reasons, often have trouble accessing timely primary care. This can contribute to the chronicity of these conditions and a reduced life expectancy of up to 25 years - the so-called "mortality gap" (Saha, Chant, \& McGrath, 2007).

One solution is to integrate a primary care provider into a mental health service, sometimes referred to as Reversed Shared Care. This can be a family physician or an advanced practice nurse whose role is to assess the physical health problems of patients using that service, initiate treatment, monitor progress, and refer on to more specialized care if required.

Providing mental health services within primary care settings. There are five ways in which mental health services can be introduced into primary care settings, in addition to co-location, where the offices of mental health and primary care providers are located in the same setting, but with no formal links or opportunities to collaborate. These are: 
- One-off visits by a mental health provider working in a mental health program for a clinical consultation, case conference, educational event, or review of cases.

- A visiting mental health team, where one or more mental health specialists visits a primary care practice regularly, for one or more half-days per week, to assess cases and offer short-term care, discuss cases with members of the primary care team, provide educational input including available community resources, assist with care coordination, and facilitate referrals to other services.

- A hub-and-spoke model, which involves outreach visits by a specialized mental health service provider to consult or provide teaching around a specific population, such as seniors, children, or individuals with addiction problems. They are usually linked to a central mental health program and will visit a practice on an as-needed basis.

- Telehealth, which is an effective way of providing services to communities where there is no psychiatrist available to visit a practice in person. While video consultation using telehealth networks is more commonly found in more remote or isolated communities, it can also be used in urban settings to reduce travel times and waiting times for service. Educational sessions can also be delivered in this way.

- Integrating mental health providers within primary care settings. This is increasingly becoming the preferred way to improve collaboration, increase access, and increase the skills and comfort of primary care providers.

\section{INTEGRATING MENTAL HEALTH PROVIDERS WITHIN PRIMARY CARE SETTINGS: THE CANADIAN APPROACH}

On the basis of experiences in almost every Canadian province, as well as lessons learned from the United States, where the Affordable Care Act and a move towards the "Patient-Centred Medical Home" catalyzed the integration of mental health specialists in primary care settings (Rainey, 2015), it is possible to identify guiding principles for effective collaboration in primary care, the components of successful programs, the competencies required of participants, tips to make the most out of integrated care, and wider system changes required to support integrated collaborative care. This Canadian Model of Collaborative Mental Health Care has many similarities with the Collaborative Care model developed by Wayne Katon and his colleagues in Seattle (Katon et al., 1995).

Canadian programs tend to focus on the needs of an entire primary care population rather than specific subgroups, and have adapted proven principles and concepts to meet local needs and respond to local demand. The most effective collaborative programs, such as the Hamilton Family Health Team, include multiple linked components combined with a redesign of existing processes of care within a practice (Kates, McPhersonDoe, \& George, 2011; Whitebird et al., 2014).

\section{Key Components of Effective Programs}

These can be divided into three groups: The key components of a collaborative model, the major activities when mental health teams are working in primary care, and other supports required to ensure the smooth running of such initiatives. 


\section{Key elements and concepts.}

- A care manager or therapist who may need to take on a variety of roles including therapist, care coordinator, case manager, educator, system navigator and family support. They may be permanently based in the practice, or there for just part of the week.

- A visiting psychiatrist who will provide consultations and selected follow-up care, discuss cases with the primary care team or mental health care manager, provide education and evidence-based guidelines, and participate in regular case reviews;

- An engaged family physician who is the lead for the project within the practice, serves as a liaison with the primary care team, and assists in solving problems as they arise. Family physicians also need to be willing to commit time to meet with the mental health team or discuss cases being seen.

- The patient as an active partner in their own care.

- The physical integration of the mental health personnel within the primary care setting, rather than just siting a clinician in an office at the end of a corridor receiving referrals without a lot of personal contact or opportunities for shared planning and goal setting is very important.

Care is:

- team-based - not only do the mental health professionals (MHPs) work closely with the primary care team, but other primary care staff such as the practice nurse, a dietitian, or a pharmacist all have a role to play in the management of individuals with mental health problems;

- evidence-informed;

- patient- and family-centred;

- focused on populations as well as individuals; and

- shared, with each provider contributing their expertise at any point in time according to the needs of the case and resource availability.

The primary aim of all programs is to obtain better outcomes for individuals with mental health and addiction problems being seen in primary care and CMHC must always be seen as a means to an end (better outcomes), rather than an end itself. To achieve this, Canadian programs have adopted one or more of the following goals:

- increasing access to care;

- expanding the capacity and capability of primary care to manage mental health problems - primary mental health care;

- enhancing the experience of care for both the patient and their family, and the providers.

Activities in integrated models. Activities can include some or all of the following, depending upon the goals of the program:

- consultations and assessments;

- ongoing care for selected individuals;

- $\quad$ psychological therapies, especially CBT and IPT; 
- care coordination and case management;

- system navigation;

- telephone follow-up or backup;

- systematic (proactive) follow-up of patients after treatment is initiated or completed (relapse prevention);

- consumer education and access to educational resources, including the use of groups;

- $\quad$ support for self-management;

- regular opportunities to meet to review cases, discuss emerging problems, provide educational input and exchange information on referrals or assessments;

- skill enhancement programs for primary care providers;

- measurement of progress once treatment is started and treating to target.

Supports required to make it work. A variety of supports, whether educational or administrative, are required to make collaborative care successful. They include:

- treatment protocols, guidelines, or pathways to guide care;

- role clarity for the MHPs;

- incentives to promote collaboration;

- $\quad$ shared record keeping;

- the use of case registries;

- $\quad$ support from leadership in both organizations; and

- links with community partners.

\section{Competencies Required to Work in an Integrated Model}

Building personal contacts is central to successful partnerships, and MHPs including psychiatrists are more successful when they invest time in getting to know their primary care colleagues. It is often the informal contacts, brief conversations, and "hallway discussions" that are the most helpful for family physicians.

MHPs require general skills in assessment and treatment and should not be too firmly wedded to a single model. The language, the culture, the timeframe, and the kinds of problems seen in primary care differ from those in secondary care, and MHPs need to understand the context in which they are working and the demands facing primary care. They need to be able to translate their language and concepts to make them relevant to the world of primary care and general medical settings. They should also be able to write notes that are succinct and don't repeat information the family physician may already have provided, with a clear, practical treatment plan and contingencies in case the plan does not work.

In other words, MHPs need to be able to "unpack" their skills and adapt them to the realities of primary care rather than just transposing traditional ways of delivering mental health care into primary care. For example, it may be unrealistic for an MHP to devote 16 weeks to a single patient for CBT if the goal 
is to promote access and patient flow. There are examples of short-term approaches to CBT and solutionfocused therapy that have demonstrated their efficacy within five sessions and may be more applicable to care delivered within a primary care context.

Consultation advice and recommendations need to be individually tailored to the skills and interests of each family physician, while educational interventions and case reports need to fit with the timeframe of a family physician's day. The psychiatrist or counsellor does not always need to be "the expert" in a shared relationship, mental health and primary care providers bring complementary knowledge and expertise, and can learn from one another. Successful collaboration marries the knowledge and understanding that primary care has of a person and their family with the specialized skills and insights that the mental health provider can bring.

To collaborate successfully, however, mental health and primary care personnel need to make adjustments. MHPs need to remember they are "guests" in someone else's home, and respect - and fit intothe routines and culture of the practice in which they're working. Primary care providers, in turn, need to be willing to adjust their working day to make time to meet and consult with members of the mental health team.

\section{Other Tips to Make Integrated Care Work}

- Preparation and orientation of mental health providers to the demands and realities of primary health care and providing ongoing support, especially during the transition, is essential.

- There needs to be a (brief) statement of the goals of the collaboration and the expectations of all participants, with a clear understanding by all of what providers can and cannot accomplish.

- It cannot be overstated how important personal contact and building relationships are between staff to enable them to get to know one another, their strengths, limitations, and interests.

- Face-to-face contact is important when transmitting information about patients and transferring care ("warm handoffs").

- Physical proximity is essential. Even small distances between staff can significantly impact the degree of collaboration within a practice and reduce the opportunities for personal contact.

- Patients and families always need to be at the centre of care. Their views, lived experiences, opinions, and voices must always be included in the planning, implementation, and evaluation process.

\section{Setting Goals and Measuring Outcomes}

Setting goals and measuring outcomes can best be accomplished by using a quality framework, such as the one developed by Sunderji and colleagues, which identifies 11 goals for collaborative care based upon Health Quality Ontario's definition of quality care and contains measures to assess the progress that programs are making toward these goals (Sunderji, Ghavam-Rassoul, Ion, \& Lin, 2017). This reflects the desire to integrate the concepts of the quality agenda into $\mathrm{CMHC}$ and incorporate the concepts of the triple aim (Berwick, Nolan, \& Whittington, 2008). 


\section{System Changes Required to Support Better Collaboration}

Collaborative mental health care flourishes when it is supported by a policy or legislation framework that promotes $\mathrm{CMHC}$ as part of health system transformation, and includes a mechanism for sharing examples of successful programs and spreading them to other communities.

Academic departments need to encourage collaboration in their training programs, provincial governments need to be willing to fund new projects and develop incentives and billing tariffs that support collaborative activity, and national and provincial professional associations need to promote collaboration among their members.

\section{Future Directions and Opportunities for Collaborative Care}

As collaborative care models become more accepted as mainstream practice in Canada, opportunities arise to take advantage of the potential these partnerships offer to address wider problems in the health care system.

Integrating physical and mental health care. The integration of mental health workers in primary care allows primary care teams to address and manage individuals with complex medical and mental health conditions and multiple problems more comprehensively, and to appreciate the interactions between the different enduring conditions. Examples of this would include medication reconciliation and focusing on the needs of specific populations, such as seniors with early cognitive impairment or teens who come for a routine visit, which can be turned into a "well teen" visit.

Early intervention and relapse prevention. Primary care is uniquely positioned to identify individuals at risk of developing a mental health problem, or to intervene when symptoms first appear. Closer surveillance after an episode of care is completed can lead to earlier detection of signs of a recurrence and relapse prevention. Both of these can be enhanced by appropriate support from mental health services.

Assisting groups that underuse mental health services. Collaborative care has demonstrated benefits in assisting populations who often underuse mental health services, including seniors, individuals residing in shelters or who are struggling with an addiction problem, and ethnocultural groups who may feel much more comfortable being seen in a primary care practice, which is more likely to be culturally congruent than a mental health service. These models can be adapted to meet the needs of other populations, such as refugees and other newcomers to Canada.

Spreading successful ideas. Mechanisms and pathways need to be developed to promote the spread of practices that have worked in one location to other communities to accelerate the uptake of these concepts by patients and providers, primarily through building regional and provincial networks.

Training future practitioners. A key to the sustainability of $\mathrm{CMHC}$ is to train learners to understand the principles and practices of working in collaborative models. All Canadian psychiatry residents, for example, now need to spend 1 to 2 months working in a collaborative care experience (usually in primary care although it can sometimes be with a community agency), where they will refine their collaborative skills and come to appreciate the role that primary care plays in delivering mental health care. 
Addressing wider system issues with access, transitions, and flow. While most projects have focused on improving access and increasing the skills and comfort of primary care providers in managing common mental health problems, collaborative care has the potential to address other challenges facing Canada's healthcare systems. Primary care practices often look after discrete populations, and by intervening sooner they can reduce avoidable emergency department visits by their patients. Primary care providers should also be centrally involved and informed during transitions between mental health services.

Reducing stigma and enhancing the person and family experience. It can be a lot more comfortable for someone to be seen in a setting that is familiar, often closer to home, and by a provider who is more likely to speak their language or understand their culture. It can also be less stigmatizing to be seen in a primary care setting as opposed to a mental health setting. In addition, increasing familiarity and comfort with individuals with mental health problems can counter preconceived biases on the part of primary care providers.

Promoting early childhood development. It is impossible to overstate the importance of addressing children's mental health needs, and the opportunities that arise in primary care to change the trajectory for children with multiple risk factors or who are coping with the consequence of adverse events. The 18-Month Well-Baby Visit can identify children who are at risk, who can then be monitored closely and proactively, ensuring they reach the services they need.

There is increasing evidence about the importance of perinatal mental health and its impact on a child's long-term well-being. Primary care is uniquely positioned to be able to address stress, depression, and anxiety in pregnant women, reducing the likelihood of a child developing mental health problems in later life.

In addition, collaborative models enable primary care to intervene more effectively with children who are the victims of adverse childhood events, mitigating their impact and reducing the likelihood of problems developing later in life.

\section{SUMMARY}

The experiences and successful examples of mental health and primary care services in Canada working collaboratively have facilitated the identification of the core components of a "made in Canada" model for collaborative mental health care that provides a framework for programs wanting to improve collaboration, and an avenue for addressing broader challenges facing Canada's health care systems. By following key concepts, and redesigning systems of care to support these models, effective programs can enhance the care and improve the outcomes for individuals with mental health and addiction problems being seen in primary care.

\section{REFERENCES}

Agency for Healthcare Research and Quality (2010). What is Integrated Behavioral Health Care (IBHC)? Rockville, MD: U.S. Department of Health and Human Services, Agency for Healthcare Research and Quality. Retrieved from http:// www.integrationacademy.ahrq.gov/products/ibhc-measures-atlas/what-integrated-behavioral-health-care-ibhc

Berwick, D. M., Nolan, T. W., \& Whittington, J. (2008). The triple aim: Care, health and cost. Health Affairs (Millwood), 27, 759-769.

College of Family Physicans of Canada. (2011). A vision for Canada: Family practice: The Patient's Medical Home. Retrieved from http://www.cfpc.ca/uploadedFiles/Resources/Resource_Items/PMH_A_Vision_for_Canada.pdf 
Craven, M., \& Bland, R. (2006). Better practices in collaborative mental health care: An analysis of the evidence base. Canadian Journal of Psychiatry, 51(Suppl. 1), 7S-72S.

Gagné, M., Dudgeon, S., \& Kates, N. (2006). Primary mental health care reform: Catch the wave. Healthcare Management Forum, 19(4), 26-31.

Kates, N. (2008). Promoting collaborative mental health care in Canada: The Canadian Collaborative Mental Health Initiative. Families, Systems, \& Health, 26(4), 466-473.

Kates, N., Arroll, B., Currie, E., Hanlon, C., Gask, L., Klasen, H., . . Williams, M. (2018): Improving collaboration between primary care and mental health services. World Journal of Biological Psychiatry. Advance online publication. https://doi.org/10.1080/15622975.2018.1471218

Kates, N., Craven, M., Bishop, J., Clinton, T., Kraftcheck, D., LeClair, K., . . Turner, T. (1997). Shared mental health care in Canada. Canadian Journal of Psychiatry, 42 (8 suppl.), i-xii.

Kates, N., MacPherson-Doe C., \& George, L. (2011). Integrating mental health services within primary care settings: The Hamilton family health team. Journal of Ambulatory Care Management, 34(2), 174-182.

Kates, N., Mazowita, G., Lemire, F., Jayabarathan, A., Bland, R., Selby, P., . . Audet, D. (2011). The evolution of collaborative mental health care in Canada: A shared vision for the future. Joint position paper of the Canadian Psychiatric Association and the College of Family Physicians of Canada. Canadian Journal of Psychiatry, 56(5), I1-I10.

Katon, W. J., Lin, E. H. B., Von Korff, M., Ciechanowski, P., Ludman, E. J., Young, B., . . McCulloch, D. (2010). Collaborative care for patients with depression and chronic illnesses. New England Journal of Medicine, 363, 2611-2620.

Katon, W. J., Von Korff, M., Lin, E., Walker, E., Simon, G. E., Bush, T., . . Russo, J. (1995). Collaborative management to achieve treatment guidelines: Impact on depression in primary care. JAMA: The Journal of the American Medical Association, 273, 1026-1031.

Lesage, A., Goering, P., \& Lin, E. (1997). Family physicians and the mental health system: A report from the mental health supplement to the Ontario health survey. Canadian Family Physician, 43, 251-256.

Mental Health Core Competencies Steering Committee. (2014). Mental health core competencies for physicians. Retrieved from http://www.royalcollege.ca/rcsite/documents/health-policy/mhcc-june-2014-e.pdf

Rainey, L. (2015). Integrating primary care and behavioral health: The role of the psychiatrist in the collaborative care model. American Journal of Psychiatry, 172, 8.

Saha, S., Chant, D., \& McGrath, J. (2007). A systematic review of mortality in schizophrenia: Is the differential mortality gap worsening over time? Archives of General Psychiatry, 64(10), 1123-1131.

Sunderji, N., Ghavam-Rassoul, A., Ion, A. \& Lin, E. (2016). Driving improvements in the implementation of collaborative mental health care: A quality framework to guide measurement, improvement and research. Technical report, Toronto, ON. https://doi.org/10.13140/RG.2.2.14312.47365

Thota, A. B., Sipe, T. A., Byard, G. J., Zometa, C. S., Hahn, R. A., McKnight-Eily, L. R., . . . Williams, S. P. (2012). Collaborative care to improve the management of depressive disorders: A community guide, systematic review, and meta-analysis. American Journal of Preventive Medicine, 42, 525-538.

Wang, P. S., Lane, M., Olfson, M., Pincus, H. A., Wells, K. B., \& Kessler, R. C. (2005). Twelve-month use of mental health services in the United States: Results from the National Comorbidity Survey Replication. Archives of General Psychiatry, 62(6), 629-640.

Whitebird, R. R., Solberg, L. I., Jaeckels, N.A., Pietruszewski, P. B., Hadzic, S., Unützer, J., . . Rubenstein, L. V. (2014). Effective implementation of collaborative care for depression: What is needed? American Journal of Managed Care, 20, 699-707. 
กั

ㄱ

호

ఫే 


\title{
Santé mentale et soins de première ligne : facteurs contribuant à la transformation du système de santé mentale au Canada
}

\author{
Nick Kates \\ McMaster University
}

\begin{abstract}
RÉSUMÉ
Depuis 20 ans, les prestataires de soins en santé mentale et de soins de santé de première ligne de partout au Canada travaillent en étroite collaboration pour améliorer l'accès aux soins, les compétences des prestataires et l'expérience des patients et patientes. Le nouveau plan stratégique de la Commission de la santé mentale du Canada (CSMC) ouvre la voie à un éventail de possibilités pour que les soins de santé collaboratifs puissent jouer un rôle dans la transformation des systèmes de santé mentale au Canada. Pour aider à formuler le plan, le présent document présente les principes qui sous-tendent les projets fructueux et explique comment il est possible pour les services de soins en santé mentale et les services de première ligne de collaborer davantage ensemble, par la voie, entre autres, de l'intégration des prestataires de soins en santé mentale au sein même des services de première ligne. Il intègre ces concepts dans un Modèle canadien de soins collaboratifs en santé mentale susceptible d'orienter le développement futur de ces approches, et propose des moyens pour qu'une collaboration plus soutenue puisse permettre de régler les problèmes plus vastes auxquels sont aujourd'hui confrontés tous les systèmes de santé du Canada.
\end{abstract}

Mots clés : soins de santé collaboratifs, soins de santé de première ligne, soins de santé intégrés

\begin{abstract}
For 20 years mental health and primary care providers across Canada have been working collaboratively together to improve access to care, provider skills, and patient experience. The new strategic plan of the
\end{abstract}

Nick Kates, Département de psychiatrie et de neurosciences comportementales, École de médecine Michael G. DeGroote, McMaster University, Hamilton (Ontario).

Aucun soutien financier n'a été accordé pour tout aspect lié à la préparation du présent document.

La correspondance concernant cet article devrait être acheminée à Nick Kates, Chef du département de psychiatrie, McMaster University, bureau B358, St. Joseph's Healthcare W 5th. Campus, 100, West 5th Street, Hamilton (Ontario) L9C 0E3. Courriel : nkates@mcmaster.ca 
Mental Health Commission of Canada (MHCC) offers many opportunities for collaborative care to play a role in the transformation of Canada's mental health systems. To assist the plan, this paper presents principles underlying successful projects and ways that mental health and primary care services can work together more collaboratively, including integrating mental health providers in primary care. It integrates these concepts into a Canadian Model for Collaborative Mental Health Care that can guide future expansion of these approaches, and suggests ways in which better collaboration can address wider issues facing all of Canada's health care systems.

Keywords: collaborative care, primary care, integrated care

Le médecin de famille ou le centre de soins de santé de première ligne est le premier point de contact avec le système de santé pour de nombreux Canadiens et Canadiennes souffrant des problèmes de santé mentale et de dépendance. Les centres de soins de santé de première ligne sont les endroits où la majorité des soins de santé mentale sont prodigués (Thota et al., 2012), y compris les soins pour les personnes ayant des problèmes médicaux complexes et des problèmes de santé mentale concomitants, et ce, souvent sans la participation d'un prestataire de soins de santé mentale spécialisés.

La prévalence des patients et patientes souffrant de problèmes de santé mentale dans les centres de soins de santé de première ligne est élevée, selon l'Agency for Healthcare Research and Quality (2010) (agence de recherche et de qualité des soins de santé), mais les médecins de famille n'ont pas tous la formation, les ressources, la confiance ou le soutien organisationnel nécessaires pour reconnaître et gérer les besoins de leurs patients et patientes. Conséquemment, ils rencontrent souvent des obstacles dans leurs relations avec les services de soins de santé mentale lorsqu'ils recherchent de l'aide. Il peut s'agir de problèmes d'accès aux services et de longs délais d'attente (Craven et Bland, 2006), de critères d'admission incohérents, de mauvaises communications et d'un manque de soutien pour la gestion de problèmes de santé mentale complexes dans leur bureau. Cela donne lieu à des soins de santé fragmentés, discontinus et mal coordonnés et impose des entraves inutiles aux patients et patientes qui tentent d'accéder aux services dont ils ont besoin ou encore qui naviguent d'un service à l'autre.

Pendant ce temps, la majorité des personnes qui souffrent de problèmes de santé mentale et de dépendance ne reçoivent aucun traitement en cours d'année (Wang et al., 2005), et leurs problèmes passent souvent inaperçus. Plus de $80 \%$ de la population consulte leur médecin de famille à chaque année (Lesage, Goering et Lin, 1997). Ce pourcentage englobe un nombre considérable de personnes ayant des problèmes de santé physique / problèmes de santé chroniques et des problèmes de santé mentale concomitants, souvent des troubles dépressifs ou anxieux (Katon et al., 2010). Cela donne à penser que le bureau du médecin de famille est peut-être l'endroit logique, parfois même le seul, pour réaliser l'identification des problèmes de santé, l'amorce des traitements et la coordination des demandes vers les services secondaires ou tertiaires.

À n'en pas douter, ces problèmes ne sont pas uniques au Canada — en réalité, la plupart des pays font face à des problèmes de nature similaire. Le Canada a néanmoins réalisé des progrès considérables au cours des 20 dernières années pour corriger ces problèmes et fournir un cadre favorable à une meilleure collaboration, afin que toute personne puisse recevoir les bons soins, du bon prestataire, le plus rapidement possible, à l'endroit le plus pratique et avec le moins d'entraves possibles (Kates, Mazowita et al., 2011) 
Le présent document passe en revue les principaux facteurs qui ont contribué à ces changements ou qui les ont influencés, recense les éléments clés à la base des initiatives canadiennes de collaboration fructueuses et décrit comment les soins de santé collaboratifs peuvent permettre de relever les défis auxquels font face tous les systèmes de soins de santé et de santé mentale au Canada. Dans son plan stratégique initial, la Commission de la santé mentale du Canada a reconnu l'importance d'une meilleure collaboration entre ces deux secteurs qui demeure un élément important de son nouveau programme.

Pour faciliter la mise en pratique des politiques, le présent document décrit les principes, les éléments clés des programmes florissants et les orientations stratégiques susceptibles d'être adaptés à n'importe quelle communauté. De fait, l'une des forces des soins collaboratifs en santé mentale (SCSM) au Canada découle de l'adaptation de ces principes afin de répondre aux besoins variés des différentes communautés et populations. Parallèlement, il paraît indispensable d'en arriver à une plus grande normalisation et à l'adoption au quotidien des pratiques qui se sont révélées efficaces au Canada comme ailleurs.

\section{ÉVOLUTION DES SOINS COLLABORATIFS EN SANTÉ MENTALE AU CANADA}

Des initiatives isolées visant à améliorer la collaboration entre les services en santé mentale et les soins de première ligne ont eu lieu dans le passé par le truchement des Centres locaux de service communautaire (CLSC) au Québec, des organismes de services de santé en Ontario et des centres de santé communautaires à travers le Canada, ainsi que par la voie de l'enrichissement des compétences des résidents et résidentes en médecine familiale en matière de gestion des problèmes de santé mentale. Qu'à cela ne tienne, les SCSM ont véritablement vu le jour en 1997 lorsque l'Association des psychiatres du Canada et le Collège des médecins de famille du Canada ont publié un énoncé conjoint de position visant à promouvoir la collaboration entre les deux secteurs de la santé (Kates et al., 1997).

Ce document de 1997 précisait l'importance pour les psychiatres, les autres prestataires de soins en santé mentale et les médecins de famille de collaborer plus étroitement et énonçait les principes permettant d'orienter l'offre des soins en collaboration (les soins partagés comme on les appelait à l'époque). Le document mettait également en évidence divers moyens pour favoriser la collaboration et soulignait l'importance de former les futurs praticiens et praticiennes pour ces modèles de pratique et les avantages que recelait l'approche dite collaborative pour les communautés et les populations mal desservies.

Cette initiative a engendré un changement remarquable dans le paysage (Kates, 2008). Dans les domaines des soins en santé mentale et des soins de santé de première ligne, les prestataires et les services ont repensé leur façon de travailler ensemble et les rôles de chacun au sein d'un système davantage intégré et coordonné. Un large éventail de projets visant à améliorer la collaboration et à établir de nouveaux partenariats ont vu le jour dans tout le pays. Ceux-ci tiraient profit des transformations à plus grande échelle des systèmes de soins de première ligne survenues au cours des 15 dernières années : le rôle attribué aux soins de première ligne comme fondement des systèmes de santé locaux et provinciaux, l'intégration d'une grande variété de professionnels et professionnelles de la santé dans des milieux de soins de première ligne pour soutenir les soins interprofessionnels complets dispensés en équipe et l'importance accrue accordée à la prévention et à la gestion des maladies chroniques. Ces nouvelles orientations sont reflétées dans le document de travail 
intitulé Une vision pour le Canada : La pratique de la médecine familiale : Un Centre de médecine de famille publié par le Collège des médecins de famille du Canada (2011).

Au sein des ministères provinciaux de la santé, les planificateurs et planificatrices des soins de première ligne et des soins en santé mentale collaborent plus étroitement à l'élaboration et au financement de projets intégrés, soit en tant qu'entités individuelles ou dans le cadre de stratégies provinciales plus globales. Ces projets comprennent les Centres de santé et de services sociaux (CSSS) au Québec, les Équipes Santé familiale en Ontario (ESF), les Primary Care Network (réseaux de soins de première ligne) en Alberta et le Practice Support Program (programme de soutien des cabinets médicaux) en Colombie-Britannique.

Au début des années 2000, deux fonds fédéraux d'innovation en soins de première ligne ont grandement stimulé les soins de santé collaboratifs. Ces fonds ont appuyé financièrement de nombreux projets de démonstration provinciaux axés sur la santé mentale et une initiative nationale de grande envergure, soit l'Initiative canadienne de collaboration en santé mentale (ICCSM). Ce projet a réuni 12 organismes nationaux représentant des prestataires, des consommateurs et consommatrices et des membres de leur famille. En 2006, l'ICCSM avait déjà établi un cadre conceptuel pour les soins de santé collaboratifs, complété un examen exhaustif de la documentation existante et élaboré des trousses d'outils en ligne pour orienter la mise en œuvre des SCSM dans des contextes généraux et pour des populations en particulier (Gagné, Dudgeon et Kates, 2006). Cette initiative a également favorisé l'élargissement des partenariats de collaboration pour inclure un plus vaste éventail de professionnels et professionnelles de la santé, notamment des infirmières, des psychologues, des travailleuses et travailleurs sociaux, des pharmaciens et pharmaciennes et des ergothérapeutes et, par-dessus tout, des consommateurs et consommatrices et des familles.

D'autres changements ont permis d'alimenter la croissance des soins de santé collaboratifs. De nombreuses provinces ont modifié leurs tarifs de facturation pour rendre possibles les consultations téléphoniques entre les psychiatres et les médecins de famille. L'Association canadienne de protection médicale a reconnu que les discussions de cas informelles - communément appelées les consultations de corridor ou au pied levé-faisaient partie intégrante de la pratique et se devaient d'être encouragées (ce qui constituait un renversement par rapport à sa position antérieure), et ce, à condition que les normes de soins acceptées pour chacune des disciplines soient respectées.

En 2010, le Collège royal des médecins et chirurgiens du Canada a fait de la formation en soins de santé collaboratifs une exigence courante pour tous les résidents et résidentes en psychiatrie, tandis que le Collège des médecins de famille du Canada a mis en place un nouveau programme communément désigné « Triple $\mathrm{C}$ » (éducation complète, continue et centrée sur la médecine familiale) qui met l'accent sur le rôle du médecin de famille dans la prestation de soins en santé mentale.

L'Association médicale canadienne continue également de promouvoir les soins de santé collaboratifs axés sur les patients et patientes auprès des spécialistes et des médecins de famille. En 2014, en partenariat avec l'Association des psychiatres du Canada, le Collège des médecins de famille du Canada et la Commission de la santé mentale du Canada, l'Association médicale canadienne a produit un document décrivant les compétences fondamentales en santé mentale que les médecins, toutes spécialités confondues, devraient acquérir au cours de leur formation (Comité directeur sur les compétences fondamentales en santé mentale, 2014). 
Ces activités et ces changements ont amené l'APC et le CMFC à revoir, en 2011, leur énoncé de position original (Kates, Mazowita et al., 2011). Tout en réaffirmant l'importance d'une meilleure collaboration et des principes qui la soutiennent, le document résumait les données concrètes attestant du succès du modèle de collaboration, soulignait les éléments clés d'une collaboration efficace, mettait en évidence des exemples de modèles fructueux observés au Canada et ailleurs et présentait un cadre d'action en vue de l'instauration d'un système intégré de santé mentale et de soins de première ligne en proposant des moyens permettant d'améliorer la collaboration. L'énoncé de position soulignait également l'importance d'apporter des changements systémiques supplémentaires et plus vastes pour soutenir les soins en collaboration et amorçait une reformulation des soins de santé collaboratifs dans le contexte d'un agenda de qualité.

Sur la base de ces solides assises et des expériences enrichissantes de nombreux partenariats fructueux ayant été établis ces 20 dernières années au Canada comme ailleurs, le présent document rassemble les éléments fondamentaux des initiatives de collaboration fructueuses mises en œuvre au Canada afin de proposer un modèle canadien de soins de santé collaboratifs. Le présent document renferme une définition commune des soins collaboratifs en santé mentale et offre une vision d'un système intégré de soins en santé mentale et de soins de première ligne. Par ailleurs, le document décrit les quatre principales approches ayant émergé au Canada pour améliorer la collaboration; les principes qui devraient sous-tendre les projets de collaboration; les composantes, les fonctions et les avantages que présentent les programmes fructueux; les soutiens systémiques plus étendus à mettre en place pour soutenir et promouvoir les soins de santé collaboratifs; et les possibilités offertes par les SCSM pour relever les défis plus vastes auxquels font face les systèmes de soins de santé au Canada.

\section{Une définition canadienne des soins collaboratifs en santé mentale}

Divers termes sont utilisés, souvent de façon interchangeable, pour décrire les partenariats de collaboration, notamment :

- les soins partagés, qui décrivent la collaboration entre deux prestataires, généralement des médecins;

- les soins intégrés - expression couramment utilisée aux États-Unis et qui, au Canada, fait référence à l'intégration des services de santé mentale dans un contexte de soins de première ligne;

- les soins de santé collaboratifs - expression la plus couramment utilisée au Canada de nos jours qui décrit les modèles et les activités dans le cadre desquels les prestataires de soins de santé mentale et de soins de première ligne (habituellement en équipe) imaginent de nouvelles façons d'œuvrer ensemble, de manière plus étroite et plus productive, par la voie des soins intégrés entre autres.

Dans un énoncé de position récent que j'ai rédigé avec un groupe de collègues, nous avons proposé la définition suivante :

Le terme soins de santé collaboratifs englobe le processus de partage des ressources, de l'expertise, des connaissances et des prises de décisions par les prestataires de soins de santé mentale et de soins de première ligne afin d'assurer aux clientèles des services de première ligne des soins de santé qui seront axés sur l'individu, efficaces et économiques et qui viendront du bon prestataire dans l'endroit le plus pratique au moment le plus opportun et avec la meilleure coordination. (Kates et al., 2018) 


\section{VISION DES RÔLES DÉVOLUS AUX SOINS DE PREMIÈRE LIGNE ET AUX SERVICES DE SANTÉ MENTALE DANS UN SYSTÈME INTÉGRÉ}

Une meilleure collaboration fournit l'occasion de diversifier et de renforcer les services susceptibles d'être offerts à l'intérieur des limites des soins de santé de première ligne. Pour en tirer pleinement parti, il est indispensable de repenser le rôle que les soins de première ligne pourraient jouer dans le cadre d'un réseau intégrant les services de soins de première ligne et les soins en santé mentale. Par ailleurs, il est essentiel de reconsidérer les différentes façons qui s'offrent aux services de santé mentale pour appuyer plus adéquatement ces nouveaux rôles.

\section{Nouveaux rôles pour les soins de première ligne}

La majorité des cabinets de soins de première ligne s'occupent d'une population dite distincte, entretiennent une relation de continuité avec leurs patients et patientes et sont souvent le premier point de contact pour les personnes atteintes de troubles mentaux ou souffrant d'un problème de dépendance. Dans l'hypothèse où le soutien approprié est disponible, les cabinets de soins de première ligne sont donc bien positionnées pour offrir des services dont la portée dépasse de loin les services de santé mentale traditionnels. Ces services comprennent :

- les interventions préventives et la promotion de la santé mentale;

- la détection précoce des problèmes de santé mentale et de dépendance;

- l'amorce plus rapide des traitements;

- le suivi médical au sortir d'un épisode de soins ou après l'obtention d'un congé d'un service de soins de santé mentale afin de prévenir les rechutes;

- l'intégration des soins physiques et émotionnels, en particulier pour les personnes ayant des troubles médicaux complexes;

- le soutien familial;

- la coordination des soins;

- la coordination des services et la navigation au sein du système.

Si les soins de première ligne sont appelés à jouer un rôle élargi dans le cadre des soins en santé mentale, alors des modifications doivent être apportées par les services de santé mentale pour soutenir ces rôles, lesquels comprennent :

- l'accès rapide à une consultation au besoin, et ce, même s'il peut toujours y avoir un temps d'attente avant de pouvoir bénéficier d'un traitement continu;

- le suivi de certaines personnes ne pouvant être prises en charge par les services de soins de première ligne (ex. : personnes ayant besoin de services de réadaptation ou devant recevoir des traitements plus spécialisés);

- la prestation de programmes dépassant la portée des soins de première ligne (c.-à-d. des programmes de réadaptation ou certains types de traitements plus spécialisés); 
- la prestation de services-conseils portant sur la gestion et les ressources communautaires;

- service permanent de soutien aux prestataires de soins de première ligne en personne, par téléphone, par courriel ou au moyen d'applications Web;

- la réévaluation rapide des personnes commençant à souffrir de décompensation;

- la formation et le renforcement des capacités des prestataires de soins de première ligne.

\section{Principes pour guider les soins de santé collaboratifs}

Quel que soit le contexte ou l'objectif visé, les projets fructueux partagent invariablement un certain nombre de caractéristiques communes. Toute initiative qui entend prospérer doit impérativement s'inspirer des principes qui guident les partenariats de collaboration efficaces et qui sont adaptés pour répondre aux besoins locaux et non simplement tenter de transposer un modèle élaboré dans un autre milieu. Chaque projet de collaboration fructueux cache en son cœur l'établissement de contacts personnels entre les prestataires de différents secteurs au moyen de communications bidirectionnelles régulières, efficaces et opportunes.

Au nombre des autres principes figurent ceux devant guider la relation entre les différents prestataires et ceux appelés à orienter la relation entre les différents services ou systèmes.

\section{Entre les prestataires individuels.}

- le respect mutuel;

- le soutien mutuel;

- la reconnaissance des forces et des limites de chacun;

- le partage de la responsabilité des soins selon les compétences, les exigences et les ressources respectives;

- la coordination des soins et des plans de soins.

\section{Entre les services.}

- la volonté de tous les partenaires d'apporter des ajustements;

- l'entente sur les objectifs d'une initiative;

- l'adaptation des modèles pour répondre aux demandes et aux besoins locaux;

- le centrage des besoins du patient ou de la patiente et de sa famille;

- le suivi régulier, l'évaluation et, au besoin, le rajustement des objectifs et des activités;

- la planification conjointe dès le premier jour.

\section{Approches pour renforcer la collaboration}

Les programmes canadiens ont généralement adopté l'une des quatre approches présentées ci-dessous pour améliorer la collaboration dans les services de santé mentale, à savoir : (a) des actions de la part des services de santé mentale pour travailler plus étroitement avec les médecins de famille locaux; (b) diverses initiatives visant à rehausser le niveau de compétence et de confort des prestataires de soins de première 
ligne dans la gestion des problèmes de santé mentale dans leur cabinet (renforcement des capacités); (c) l'intégration des prestataires de soins de première ligne aux programmes de santé mentale; et (d) l'intégration des services de santé mentale aux soins de première ligne.

Collaboration plus étroite avec les médecins. Un service de santé mentale peut faire bien des choses pour travailler davantage en collaboration, l'éventail des options ayant tendance à s'élargir lorsqu'on observe une plus grande proximité et des contacts personnels réguliers. Bon nombre des idées proposées ici peuvent être mises de l'avant à un coût modeste, voire nul, par tout service de santé mentale. Celles-ci comprennent l'amélioration des communications entre les prestataires de services, des consultations de meilleure qualité et plus rapides et une meilleure coordination des soins de santé.

Pour un service de santé mentale, une première étape simple consiste à demander aux médecins de famille de proximité, au moyen de sondages, de discussions lors de rencontres ou de petits groupes de discussion, leur avis sur l'état de la collaboration et des conseils sur les moyens à prendre pour renforcer le partenariat et mieux répondre aux besoins des médecins.

L'élaboration de protocoles pour communiquer avec le médecin de famille lors de l'admission d'une personne à un service, lorsque s'amorce le processus de planification du congé, lors d'un changement de médication et lorsqu'il s'agit de référer un dossier à un autre service, contribue à normaliser l'adoption de pratiques optimales. Cela peut être facilité par la simplification des procédures d'admission et des critères d'inclusion ou d'exclusion qui, bien souvent, n'ont guère de sens pour la source de référence.

La transmission rapide de rapports contenant des renseignements pertinents et pratiques et un plan de traitement clair sont toujours des mesures utiles. Communiquer avec le médecin de famille — ou le patient ou la patiente - de façon routinière une semaine et un mois après le congé pour vérifier si les contacts ont été établis s'avère une démarche susceptible de faciliter la mise en œuvre du plan.

Bien que la consultation traditionnelle en personne avec un patient ou une patiente demeure une activité centrale pour un service de santé mentale, d'autres moyens s'offrent au médecin de famille pour obtenir des informations utiles sur une personne, notamment les consultations téléphoniques et, de plus en plus souvent, les communications par courriel. Si les renseignements permettant d'identifier le patient ou la patiente ne sont pas échangés, il peut alors être facile et rapide de poser des questions et d'obtenir des réponses.

Pour améliorer l'accès aux soins, certains services de santé mentale dont les délais d'attente pour les services courants sont relativement élevés (plus de 3 mois) ont mis sur pied des services de consultation rapide afin de pouvoir rapidement offrir de l'aide médicale et des traitements initiaux / conseils de gestion aux médecins de famille, les noms des leurs patients et patientes étant ensuite réinscrits sur la liste d'attente pour les soins courants si nécessaire. L'équipe de santé mentale peut continuer de fournir des conseils ou du soutien téléphonique aux médecins de famille jusqu'à ce que leurs patients et patientes soient pris en charge ou que leurs problèmes soit réglés.

Les personnes souffrant de problèmes de santé mentale sont souvent désavantagées par la fragmentation des services de santé mentale et peuvent avoir de la difficulté à naviguer aisément d'un service ou d'un secteur à un autre. Une clarté inébranlable quant à la responsabilité respective de chacune des parties impliquées dans la réalisation du plan de soins peut contribuer à réduire ces défis, tout comme la souplesse des critères d'admission. 
L'élaboration d'un plan de traitement personnalisé concis, ciblé et fonctionnel constitue une étape cruciale. Idéalement, on devrait remettre à la personne concernée une copie du plan qu'elle peut avoir en sa possession lors de ses rendez-vous, permettant ainsi à tous les professionnelles et professionnels impliqués dans le dossier de connaître la teneur du plan. La coordination peut également être améliorée par la création d'une liste de contrôle de la planification des congés qui énumère les étapes toutes simples que les prestataires d'un service devraient suivre de routine. Un prestataire de soins de santé mentale peut également prendre les dispositions nécessaires pour que le rendez-vous précédant la signification du congé au patient ou à la patiente ait lieu au bureau du médecin de famille, afin de s'assurer que toutes les parties concernées connaissent bien le plan et les responsabilités incombant à chacune d'elles.

Renforcement des capacités des prestataires de soins de première ligne. Ces initiatives visent à rehausser le niveau de compétence et de confort des médecins de famille et des autres prestataires de soins de première ligne pour reconnaître et gérer les problèmes de santé mentale à l'étape des soins de première ligne, ce qui élargit la gamme de soins efficaces offerts à ce niveau de service.

Les ateliers et les présentations de formation continue peuvent s'avérer des outils et des activités fort efficaces, pourvu qu'ils soient relativement brefs, axés sur la résolution de cas ou de problèmes, interactifs et adaptés aux réalités et aux exigences des soins de première ligne. Ces outils et ces activités de formation doivent également aborder des sujets choisis par les médecins de famille et faire appel à la participation autant des médecins de famille que des spécialistes en tant que présentateurs et présentatrices. Enfin, ils doivent aussi faire l'objet d'un suivi après coup pour éviter d'être catalogués comme simples « actions ponctuelles », susceptibles d'être facilement oubliées.

Par ailleurs, la visite de centres de soins de première ligne par les spécialistes en santé mentale peut se hisser au rang des activités éducatives respectant les principes énoncés ci-dessus et ouvrant de nouvelles possibilités d'apprentissage. Les options d'enrichissement qui s'offrent comprennent l'organisation de présentations axées sur la résolution de cas ou de problèmes associés à un thème spécifique ou encore la discussion et l'évaluation de cas rencontrés par les médecins de famille. Tous les cas faisant l'objet de consultations offrent des possibilités d'apprentissage sur les enjeux qu'ils soulèvent.

Des informations peuvent également être fournies sur des outils pratiques comme les instruments de dépistage, les lignes directrices de prise en charge, les ressources pour les patients et patientes, les programmes communautaires, etc. Ces informations peuvent être regroupées sur un seul site Web, facilement accessible, ou encore incorporées dans un dossier médical électronique, en vue d'améliorer les différentes facettes de la prestation des soins de santé mentale. Il peut aussi être utile de communiquer aux prestataires de soins de première ligne des liens Web vers des documents en ligne facilement utilisables et téléchargeables portant sur des sujets comme le développement de compétences en matière d'autogestion par une personne déprimée.

Certains programmes plus exhaustifs, comme le Practice Support Program (programme de soutien des cabinets médicaux) de la Colombie-Britannique, ont intégré tous ces éléments dans leur module sur la santé mentale adulte (SMA), un programme de formation et de soutien à l'intention des médecins et de leurs assistantes et assistants médicaux. La ressource en ligne comprend des outils de dépistage et d'évaluation qui présentent un système structuré, fondé sur des lignes directrices pour les médecins et qui incorporent des processus d'autogestion pour permettre aux patients et patientes de devenir des partenaires actifs dans 
le traitement de leur santé mentale. Dans le cadre de ce programme, un module a également été élaboré à l'intention des enfants et des adolescents et adolescentes. Celui-ci a été lancé avec succès en NouvelleÉcosse et au Yukon.

Intégration des prestataires de soins de première ligne au sein des services de santé mentale. Les personnes atteintes de maladies mentales graves et persistantes sont plus à risque de développer des problèmes de santé chroniques comme le diabète, les maladies vasculaires et les problèmes respiratoires. Pour diverses raisons, ces personnes ont souvent de la difficulté à accéder aux soins de première ligne en temps opportun. Cette situation peut contribuer à la chronicité de ces conditions et à une réduction de l'espérance de vie pouvant atteindre 25 ans_-le soi-disant « écart de mortalité » (Saha, Chant et McGrath, 2007).

Une solution consiste à intégrer un prestataire de soins de première ligne au service de santé mentale. L'expression soins partagés à l'inverse (Reversed Shared Care) est parfois utilisée pour décrire une telle démarche. Le prestataire de soins de première ligne en question peut être un médecin de famille ou un infirmier ou une infirmière en pratique avancée dont les tâches consistent à évaluer les problèmes de santé physique des patients et patientes ayant recours à ce service, à amorcer les traitements et à suivre les progrès des patients et patientes en vue de les diriger vers des soins plus spécialisés au besoin.

Services de santé mentale dispensés dans le contexte des soins de première ligne. Exclusion faite de la formule de la simple cohabitation des services dans le cadre de laquelle les prestataires de soins de santé mentale et de soins de première ligne partagent un environnement commun, sans toutefois entretenir de relations officielles ou établir une coopération, on dénombre cinq autres façons dont les services de santé mentale peuvent être intégrés aux centres de soins de première ligne. Ces cinq approches sont énumérées ci-dessous :

- Organisation de visites ponctuelles effectuées par un prestataire de services de santé mentale participant à un programme de santé mentale pour la tenue de consultations cliniques, de conférences de cas, d'événements éducatifs ou d'examens de cas.

- Formation d'une équipe de santé mentale ambulatoire composée d'un ou de plusieurs spécialistes de la santé mentale qui a comme fonction de visiter sur une base régulière, soit au moins une demi-journée chaque semaine, un service de soins de première ligne pour procéder à l'évaluation de cas, offrir des soins de courte durée, discuter des cas avec les membres de l'équipe de soins de première ligne, fournir un accompagnement éducatif portant notamment sur la présentation des ressources communautaires disponibles, aider à la coordination des soins et faciliter l'aiguillage vers d'autres services.

- Élaboration d'un modèle en étoile qui repose notamment sur des visites de sensibilisation effectuées par un prestataire de services spécialisés en santé mentale qui propose des consultations ou qui se rend disponible pour offrir des enseignements à une population donnée (ex. : les personnes âgées, les enfants ou les personnes ayant des problèmes de dépendance). Les réseaux en étoile sont généralement associés à un programme central de santé mentale, et leurs visites dans les cabinets s'effectuent au fur et à mesure des besoins.

- La télésanté est un moyen efficace pour fournir des services aux collectivités où aucun psychiatre n'est disponible pour visiter les cliniques en personne. La consultation vidéo via les réseaux de 
télésanté est une pratique plus fréquente dans les collectivités éloignées ou isolées, mais la télésanté peut également être utilisée en milieu urbain pour réduire les temps de déplacement et les délais d'attente pour les services. Des séances d'éducation peuvent également être offertes au moyen de la télésanté.

- L'intégration des prestataires de soins de santé mentale au sein des centres de soins de première ligne. C'est le moyen de plus en plus privilégié pour améliorer la collaboration, accroître l'accès et rehausser les compétences et le niveau de confiance des prestataires de soins de première ligne.

\section{INTÉGRATION DES PRESTATAIRES DE SOINS DE SANTÉ MENTALE AU SEIN DES CENTRES DE SOINS DE PREMIÈRE LIGNE : L'APPROCHE CANADIENNE}

Sur la base des expériences menées dans la presque totalité des provinces canadiennes et des leçons tirées des États-Unis, où l'Affordable Care Act (loi sur les soins abordables) et le mouvement de transition vers le « Patient-Centred Medical Home » (centre médical axé sur les patients et patientes) ont catalysé l'intégration des spécialistes en santé mentale dans le contexte des soins de première ligne (Rainey, 2015), il est possible d'identifier les principes directeurs régissant les processus de collaboration efficaces dans les soins de première ligne, les composantes essentielles des programmes couronnés de succès, les compétences requises des participants et participantes pour tirer le meilleur parti des soins intégrés et les changements systémiques plus vastes nécessaires pour soutenir adéquatement les soins de santé collaboratifs. Le Modèle canadien de soins collaboratifs en santé mentale présente de nombreuses similitudes avec le Modèle de soins de santé collaboratifs élaboré par Wayne Katon et ses collègues à Seattle (Katon et al., 1995).

Les programmes canadiens ont adapté des principes et des concepts éprouvés pour répondre aux besoins et aux demandes des populations locales. Dans les faits, ils ont tendance à mettre l'accent sur les besoins de toute une population de soins de première ligne plutôt que sur les besoins de sous-groupes particuliers. Les programmes de collaboration les plus efficaces comme le Hamilton Family Health Team (l'Équipe de santé familiale de Hamilton), comprennent de multiples composantes interconnectées et tablent sur une refonte des processus de soins existants au sein des cabinets médicaux (Kates, McPherson-Doe et George, 2011; Whitebird et al., 2014).

\section{Éléments clés des programmes efficaces}

Ceux-ci peuvent être divisés en trois groupes : les éléments clés d'un modèle de collaboration; les principales activités menées par les équipes de santé mentale travaillant en soins de première ligne; et les autres mesures de soutien nécessaires pour assurer le bon fonctionnement de telles initiatives.

\section{Éléments et concepts clés.}

- Un gestionnaire de soins ou un thérapeute pouvant être appelé à tenir divers rôles, dont ceux de thérapeute, de coordonnateur ou coordinatrice des soins, de gestionnaire de cas, d'éducateur ou éducatrice, de navigateur ou navigatrice de système et de soutien familial. Le gestionnaire de soins / thérapeute peut œuvrer de façon permanente au sein du cabinet médical ou encore y travailler seulement une partie de la semaine. 
- Un psychiatre en visite qui offrira des consultations et prodiguera des soins de suivi ciblés, discutera des cas avec les membres de l'équipe de soins de première ligne ou le gestionnaire de soins de santé mentale, présentera des lignes directrices en matière d'éducation et des directives fondées sur des données probantes et participera à des analyses de cas sur une base régulière.

- Un médecin de famille engagé qui dirige le projet au sein du cabinet médical, assure la liaison avec l'équipe de soins de première ligne et aide à résoudre les problèmes au fur et à mesure qu'ils surviennent. Les médecins de famille doivent aussi être disposés à consacrer de leur temps pour rencontrer les membres de l'équipe de santé mentale ou pour discuter de dossiers actifs.

- Le patient ou la patiente en tant que partenaire actif dans la prise en charge de ses propres soins.

- L'intégration physique du personnel des services de santé mentale au sein des services de soins de première ligne préférablement à simplement poster un clinicien ou une clinicienne dans un bureau, en retrait dans un corridor, où il reçoit les patients et patientes qui lui sont référés, dans un contexte où les contacts personnels et les occasions de planification et d'établissement d'objectifs en commun sont limités, et ce, en dépit de l'importance capitale qu'ils revêtent.

Les soins sont des services :

- dispensés en équipe-les professionnels et professionnelles de la santé mentale (PSM) travaillent en étroite collaboration avec l'équipe de soins de première ligne dont certains membres comme l'infirmière ou l'infirmier du cabinet médical, le diététiste ou le pharmacien ou la pharmacienne ont un rôle à jouer lors de la prise en charge des personnes souffrant de problèmes de santé mentale;

- fondés sur des choix éclairés;

- centrés sur le patient ou la patiente et la famille;

- axés sur les populations et les individus;

- partagés, chaque prestataire apportant son expertise à tout moment, en fonction des besoins des patients et patientes et de la disponibilité des ressources.

L'objectif premier de tous les programmes est l'obtention de meilleurs résultats pour les personnes qui souffrent de problèmes de santé mentale et de dépendance et qui sont accueillies par les services de première ligne. À cet égard, les SCSM doivent toujours être considérés comme un moyen de parvenir à une fin (de meilleurs résultats) et non comme une fin en soi. Pour ce faire, les programmes canadiens ont adopté un ou plusieurs des objectifs suivants :

- l'amélioration de l'accessibilité aux soins;

- l'accroissement de la capacité des services de première ligne à gérer les problèmes de santé mentale-soins de santé mentale primaires;

- l'enrichissement de l'expérience du patient ou de la patiente, de sa famille et des prestataires de soins.

Activités menées dans le cadre des modèles intégrés. Selon les objectifs du programme, les activités poursuivies peuvent comprendre un certain nombre ou l'ensemble des éléments suivants :

- consultations et évaluations;

- prestation de soins continus pour les individus sélectionnés; 
- thérapies psychologiques, en particulier les thérapies TCC et TPI;

- coordination des soins et gestion des dossiers;

- $\quad$ système de navigation;

- suivi ou soutien téléphonique;

- suivi systématique (proactif) des patients et patientes, à l'amorce ou à la fin des traitements (prévention des rechutes);

- éducation des consommateurs et consommatrices et accès aux ressources éducatives, y compris le recours à des groupes de discussion;

- soutien à l'autogestion;

- multiplication des occasions de se réunir pour examiner les cas, discuter des nouveaux problèmes, fournir des commentaires éducatifs et échanger de l'information sur les références ou les évaluations;

- mise sur pied de programmes d'amélioration des compétences destinés aux prestataires de soins de première ligne;

- évaluation des progrès une fois les traitements amorcés et jusqu'à l'atteinte des objectifs visés.

Mesures de soutien nécessaires au bon fonctionnement. Diverses mesures de soutien, qu'elles soient de nature éducatives ou administratives, sont nécessaires pour assurer la réussite des soins de santé dits collaboratifs. Celles-ci comprennent :

- mise en place de protocoles de traitement, de lignes directrices ou de voies à suivre pour orienter les soins prodigués;

- clarification du rôle joué par les PSM;

- mise en œuvre de mesures incitatives pour promouvoir la collaboration;

- mise en place d'un système commun de tenue des dossiers;

- utilisation de registres des cas;

- obtention du soutien de la direction des deux organisations;

- création de liens avec les partenaires communautaires.

\section{Compétences requises pour œuvrer au sein d'un modèle intégré}

L'établissement de contacts personnels est essentiel pour assurer le succès des partenariats, et les PSM, les psychiatres entre autres, obtiennent de meilleurs résultats lorsqu'ils investissent du temps pour mieux connaître leurs collègues des services de première ligne. Les contacts informels, les entretiens brefs et les « discussions de couloir » constituent bien souvent les formes d'échange les plus utiles aux médecins de famille.

Pour accomplir leur travail, les PSM doivent posséder des compétences générales en matière d'évaluation et de traitement. En revanche, les PSM ne doivent pas faire preuve d'une fidélité excessive envers un seul modèle opérationnel. Le langage, la culture, les délais de traitement et la nature des problèmes rencontrés 
dans le cadre des services de première ligne diffèrent de ceux inhérents aux services de deuxième ligne, et les PSM doivent comprendre le contexte dans lequel ils travaillent et tenir compte des exigences particulières auxquelles doivent se conformer les services de première ligne. Ils doivent parvenir à traduire de façon compréhensible leur langage et leurs concepts afin de les rendre pertinents aux intervenants et intervenantes de première ligne et à l'ensemble du monde médical. Ils doivent également parvenir à rédiger des notes de travail succinctes, exemptes d'informations susceptibles d'avoir déjà été fournies par le médecin de famille. Enfin, les PSM doivent préparer un plan de traitement clair et pratique de même qu'un plan de contingence au cas où le plan d'action jugé prioritaire échouerait.

Autrement dit, les PSM doivent être en mesure de « déballer » leurs compétences et de les adapter aux réalités des services de santé de première ligne plutôt que de simplement transposer les façons traditionnelles de fournir des soins de santé mentale aux services de première ligne. À titre d'exemple, il serait probablement irréaliste pour un PSM de consacrer 16 semaines à un seul patient pour une thérapie TCC, si l'objectif visé est d'améliorer l'accès et le flux des patients et patientes. Il existe des exemples de thérapies TCC et de thérapies axées sur la recherche de solutions relativement succinctes qui ont démontré leur efficacité après seulement cinq séances et qui pourraient s'appliquer davantage aux types de soins prodigués dans le cadre des services de première ligne.

Les conseils et les recommandations doivent être personnalisés pour s'adapter aux compétences et aux champs d'intérêt de chaque médecin de famille, alors que les interventions éducatives et les rapports d'observation doivent pouvoir s'ajuster à l'horaire de travail du médecin de famille. Le psychiatre ou le conseiller ou la conseillère n'a pas toujours besoin d'être « l'expert» dans une relation commune. De fait, les PSM et les prestataires de soins de première ligne apportent avec eux des connaissances et une expertise complémentaires, ce qui leur permet de pouvoir en apprendre beaucoup les uns des autres. Les collaborations fructueuses concilient les connaissances et la compréhension que les services de première ligne ont d'une personne et de sa famille avec les compétences spécialisées et les impressions que le prestataire de soins de santé mentale peut se charger d'apporter.

Cependant, pour que la collaboration soit fructueuse, il est indispensable que le personnel des services de santé mentale et celui des soins de première ligne procèdent à des ajustements. Les PSM doivent se rappeler qu'ils ne sont que des « invités » chez quelqu'un d'autre et qu'ils doivent respecter-voire s'intégrer à-la routine et la culture du cabinet médical au sein duquel ils œuvrent. De leur côté, les prestataires de soins de première ligne doivent être disposés à adapter leur journée de travail en s'accordant du temps pour rencontrer et consulter les membres de l'équipe de santé mentale.

\section{Autres conseils pour assurer le succès de la prestation de soins intégrés}

- Pour les prestataires de soins de santé mentale, la préparation et l'adaptation aux exigences et aux réalités des services de première ligne est une condition essentielle, tout autant que d'accorder un soutien continu, particulièrement lorsque s'effectue la transition.

- La nécessité s'impose d'un énoncé (bref) des objectifs visés par la collaboration, des attentes de tous les participants et participantes et d'une bonne compréhension de la part de tous les intervenants et intervenantes de ce que les prestataires peuvent et ne peuvent accomplir. 
- On ne saurait trop insister sur l'importance des contacts personnels et l'établissement de relations harmonieuses pour permettre aux membres des différentes équipes de mieux se connaitre et d'être pleinement conscients de leurs forces, de leurs limites et de leurs intérêts respectifs.

- Les contacts en personne sont importants pour transmettre de l'information sur les patients et patientes et procéder au transfert de la responsabilité des soins (« transferts chaleureux »).

- La proximité physique est essentielle. Même les petites distances qui séparent entre eux les membres du personnel peuvent avoir une incidence importante sur le degré de collaboration au sein d'un cabinet médical et réduire les possibilités de contact personnel.

- Les patients et patientes et leurs familles doivent toujours être au cœur des soins. Leurs points de vue, leurs expériences de vie, leurs opinions et leurs voix doivent toujours être inclus dans le processus de planification, de mise en œuvre et d'évaluation.

\section{Établir des objectifs et mesurer les résultats}

La meilleure façon d'atteindre les objectifs et de mesurer les résultats est d'utiliser un cadre d'assurance de la qualité comme celui élaboré par Sunderji et ses collègues, lequel définit 11 objectifs pour les soins de santé collaboratifs s'inspirant de la définition de soins de santé de qualité de l'organisme Qualité des services de santé Ontario, laquelle renferme des mesures permettant d'évaluer les progrès réalisés par les programmes vers l'atteinte de ces objectifs (Sunderji, Ghavam-Rassoul, Ion et Lin, 2017). Cela reflète la volonté d'intégrer les concepts du programme d'amélioration de la qualité aux SCSM et d'incorporer les concepts du triple objectif (Berwick, Nolan et Whittington, 2008).

\section{Modifications devant être apportées au système pour favoriser une meilleure collaboration}

Les soins collaboratifs en santé mentale s'avèrent florissants lorsqu'ils bénéficient du soutien d'un cadre réglementaire ou législatif faisant la promotion des SCSM comme faisant partie de la transformation du système de santé et comprenant un mécanisme de partage d'exemples de programmes fructueux et de diffusion vers d'autres communautés.

Les départements des établissements universitaires doivent encourager les solutions qui favorisent la collaboration dans leurs programmes de formation. De leur côté, les gouvernements provinciaux doivent être disposés à financer de nouveaux projets et à élaborer des mesures et des modalités de tarification incitatives qui soutiennent les activités de collaboration. Enfin, les associations professionnelles nationales et provinciales doivent promouvoir l'esprit de collaboration chez leurs membres.

\section{Orientations futures et possibilités de développement des soins de santé collaboratifs}

À mesure que les modèles de soins de santé collaboratifs sont plus largement acceptés comme pratique courante au Canada, des occasions se présentent pour tirer parti du potentiel que recèlent ces partenariats pour résoudre les problèmes plus vastes constatés dans le système de santé.

Intégration des soins de santé physique et mentale. L'intégration des PSM au sein des services de première ligne permet aux équipes de soins de première ligne de traiter et de gérer de façon plus exhaustive 
les personnes ayant des problèmes médicaux et mentaux complexes et vivant diverses autres problématiques, et d'apprécier la portée des interactions entre les différentes conditions persistantes. Quelques exemples d'une telle approche comprendraient la réalisation de bilans comparatifs des médicaments et l'accent pouvant être mis sur la satisfaction des besoins de populations particulières comme les personnes âgées atteintes d'une déficience cognitive précoce ou encore les adolescents et adolescentes, dont la visite de routine pourrait devenir un bilan de santé.

Intervention précoce et prévention des rechutes. Les services de première ligne se trouvent dans une position particulièrement avantageuse pour identifier les personnes à risque de développer des problèmes de santé mentale ou pour intervenir dès l'apparition des premiers symptômes. Une surveillance plus étroite après un épisode de soins permet de détecter plus rapidement les signes de récurrence et d'améliorer la prévention des rechutes. Ces deux actions peuvent être renforcées grâce au soutien approprié des services de santé mentale.

Assistance aux groupes qui sous-utilisent les services de santé mentale. Les soins de santé collaboratifs se sont révélés bénéfiques pour venir en aide aux populations qui sous-utilisent bien souvent les services de santé mentale, par exemple les personnes âgées, les personnes qui vivent dans des refuges ou qui sont aux prises avec un problème de dépendance, et les membres de certains groupes ethnoculturels qui se sentent beaucoup plus à l'aise d'être vus dans des centres de soins de première ligne, lieux davantage compatibles avec leur réalité culturelle, que les centres de services de santé mentale. Ces modèles peuvent être adaptés pour répondre aux besoins d'autres populations comme les réfugiés et certains groupes de nouveaux arrivants au Canada.

Diffusion des idées séduisantes. Des mécanismes et des voies de communication doivent être élaborés pour favoriser la diffusion, à travers les communautés, des pratiques qui ont connu du succès dans d'autres endroits, et ce, afin d'accélérer l'adoption de ces concepts par les patients et patientes et les prestataires, notamment via l'établissement de réseaux régionaux et provinciaux.

Formation des futurs praticiens et praticiennes. L'une des conditions essentielles à la viabilité des SCSM réside dans la formation des apprentis et apprenties afin qu'ils embrassent les principes et les méthodes de travail au sein de modèles de pratique en collaboration. À titre d'exemple, au Canada, tous les résidents et résidentes en psychiatrie doivent désormais œuvrer de 1 à 2 mois dans un centre de soins de santé collaboratifs (habituellement dans un contexte de services de première ligne ou, à l'occasion, au sein d'un organisme communautaire) où ils parviennent à améliorer leurs aptitudes à la collaboration et à apprécier le rôle que jouent les services de soins primaires dans la prestation de soins en santé mentale.

Résolution des problèmes plus larges du système via les processus d'accès, de transition et de gestion de l'affluence. À ce jour, la plupart des projets ont mis l'accent sur l'amélioration de l'accès, l'enrichissement des compétences et le rehaussement du niveau de confiance des prestataires de soins de première ligne dans la gestion des problèmes de santé mentale les plus courants. Malgré tout, les soins de santé collaboratifs permettent de s'attaquer à d'autres défis auxquels font face les systèmes de santé au Canada. Bien souvent, les services de santé de première ligne traitent des populations plus effacées. En intervenant plus tôt dans le processus, ils peuvent contribuer à réduire les visites évitables des patients et patientes aux services 
d'urgence. Au final, les prestataires de soins de première ligne devraient être des joueurs clés, en tout temps informés de l'avancement des dossiers durant le processus de transition entre les services de santé mentale.

Réduction de la stigmatisation et rehaussement de l'expérience individuelle et familiale. Il peut être beaucoup plus rassurant pour un patient ou une patiente d'être vu dans un contexte qui lui est plus familier, souvent à proximité de chez lui, par un prestataire de soins davantage susceptible de parler sa langue ou de comprendre sa culture. Il peut aussi être moins stigmatisant pour un patient ou une patiente d'être vu dans un contexte de services de première ligne plutôt que dans un milieu clinique de santé mentale. De plus, le sentiment de familiarité accru envers les patientes et patients atteints de problèmes de santé mentale, combiné à une meilleure compréhension de leur réalité, peut contribuer à faire tomber les préjugés que pourraient entretenir les prestataires de soins de première ligne à leur égard.

Promotion du développement des jeunes enfants. On ne peut trop insister sur l'importance de répondre aux besoins des enfants sur le plan de la santé mentale. Par ailleurs, on ne peut passer sous silence les possibilités qui s'ouvrent du côté des services de première ligne pour modifier favorablement la trajectoire des enfants qui présentent de multiples facteurs de risque ou qui portent en eux les séquelles d'événements indésirables. Le bilan de santé des bébés bien portants à 18 mois permet d'identifier les enfants à risque, lesquels peuvent ensuite faire l'objet d'un suivi proactif et rigoureux afin qu'ils obtiennent les services dont ils ont besoin.

Des indices de plus en plus nombreux pointent vers l'importance de la santé mentale périnatale et son incidence sur le bien-être des enfants à long terme. À cet égard, les services de première ligne sont particulièrement bien positionnés pour traiter le stress, la dépression et l'anxiété chez les femmes enceintes, réduisant ainsi la probabilité qu'un enfant développe des problèmes de santé mentale plus tard dans sa vie.

Grâce aux modèles de soins collaboratifs, les services de première ligne peuvent également intervenir plus efficacement auprès des enfants victimes d'événements indésirables survenus plus tôt dans leur vie en atténuant l'impact desdits traumatismes et en réduisant la probabilité que des problèmes surviennent plus tard dans la vie.

\section{EN SOMME}

Les expériences tirées des exemples fructueux de services de première ligne et de soins en santé mentale œuvrant dans un esprit de collaboration au Canada ont facilité l'identification des éléments fondamentaux que nous devrions retrouver dans un modèle de soins collaboratifs en santé mentale " fait au Canada » qui fournirait à la fois un cadre de développement aux programmes de soins de santé souhaitant rehausser l'esprit de collaboration qui les anime et un moyen de relever les défis plus vastes auxquels font face les systèmes de santé au Canada. En adhérant aux concepts clés proposés par les modèles de soins collaboratifs et en procédant à la refonte des systèmes de soins pour qu'ils confirment la validité de tels modèles, les programmes de santé efficaces peuvent améliorer la qualité des soins prodigués et améliorer la condition des personnes qui souffrent de problèmes de santé mentale et de dépendance et qui obtiennent des traitements dans les services de première ligne. 


\section{RÉFÉRENCES}

Agency for Healthcare Research and Quality. (2010). What is Integrated Behavioral Health Care (IBHC)? Rockville, MD: U.S. Department of Health and Human Services, Agency for Healthcare Research and Quality. Récupéré de http:// www.integrationacademy.ahrq.gov/products/ibhc-measures-atlas/what-integrated-behavioral-health-care-ibhc

Berwick, D. M., Nolan, T. W. et Whittington, J. (2008). The triple aim: Care, health and cost. Health Affairs (Millwood), $27,759-769$.

Collège des médecins de famille du Canada. (2011). Une vision pour le Canada : la pratique de la médecine familiale: le Centre de médecine de famille. Récupéré de http://www.cfpc.ca/uploadedFiles/Resources/Resource_Items/ CMF_Une_Vision_Pour_le_Canada.pdf

Comité directeur sur les compétences fondamentales en santé mentale. (2014). Compétences fondamentales en santé mentale pour les médecins. Récupéré de http://www.royalcollege.ca/rcsite/documents/health-policy/mhcc-june2014-f.pdf

Craven, M. et Bland, R. (2006). Better practices in collaborative mental health care: An analysis of the evidence base. Revue canadienne de psychiatrie, 51 (suppl. 1), 7S-72S.

Gagné, M., Dudgeon, S. et Kates, N. (2006). Primary mental health care reform: Catch the wave. Forum gestion des soins de santé, 19(4), 26-31.

Kates, N. (2008). Promoting collaborative mental health care in Canada: The Canadian Collaborative Mental Health Initiative. Families, Systems, \& Health, 26(4), 466-473.

Kates, N., Arroll, B., Currie, E., Hanlon, C., Gask, L., Klasen, H., [. . .] Williams, M. (2018): Improving collaboration between primary care and mental health services. World Journal of Biological Psychiatry. Publication avancée en ligne. https://doi.org/10.1080/15622975.2018.1471218

Kates, N., Craven, M., Bishop, J., Clinton, T., Kraftcheck, D., LeClair, K., [. . .] Turner, T. (1997). Les soins de santé mentale partagés au Canada. Association canadienne des psychiatres, document de référence. Récupéré de https:// www.cpa-apc.org/wp-content/uploads/Shared-Mental-Health-Care_FRE-web.pdf

Kates, N., MacPherson-Doe, C. et George, L. (2011). Integrating mental health services within primary care settings: The Hamilton family health team. Journal of Ambulatory Care Management, 34(2), 174-182.

Kates, N., Mazowita, G., Lemire, F., Jayabarathan, A., Bland, R., Selby, P., [. . .] Audet, D. (2011). L'évolution des soins de santé mentale en collaboration au Canada : une vision d'avenir partagée. Énoncé de principes de l'Association des psychiatres du Canada et du Collège des médecins de famille du Canada. Revue canadienne de psychiatrie, 56(5), I1-I10.

Katon, W. J., Lin, E. H. B., Von Korff, M., Ciechanowski, P., Ludman, E. J., Young, B., [ . .] McCulloch, D. (2010). Collaborative care for patients with depression and chronic illnesses. New England Journal of Medicine, 363, 2611-2620.

Katon, W. J., Von Korff, M., Lin, E., Walker, E., Simon, G. E., Bush, T., [. . .] Russo, J. (1995). Collaborative management to achieve treatment guidelines: Impact on depression in primary care. JAMA: The Journal of the American Medical Association, 273, 1026-1031.

Lesage, A., Goering, P. et Lin, E. (1997). Family physicians and the mental health system: A report from the mental health supplement to the Ontario health survey. Le médecin de famille canadien, 43, 251-256.

Rainey, L. (2015). Integrating primary care and behavioral health: The role of the psychiatrist in the collaborative care model. American Journal of Psychiatry, 172, 8.

Saha, S., Chant, D. et McGrath, J. (2007). A systematic review of mortality in schizophrenia: Is the differential mortality gap worsening over time? Archives of General Psychiatry, 64(10), 1123-1131.

Sunderji, N., Ghavam-Rassoul, A., Ion, A. et Lin, E. (2016). Driving improvements in the implementation of collaborative mental health care: A quality framework to guide measurement, improvement and research. Rapport technique, Toronto, ON. https://doi.org/10.13140/RG.2.2.14312.47365

Thota, A. B., Sipe, T. A., Byard, G. J., Zometa, C. S., Hahn, R. A., McKnight-Eily, L. R., [ . . ] Williams, S. P. (2012). Collaborative care to improve the management of depressive disorders: A community guide, systematic review, and meta-analysis. American Journal of Preventive Medicine, 42, 525-538. 
Wang, P. S., Lane, M., Olfson, M., Pincus, H. A., Wells, K. B. et Kessler, R. C. (2005). Twelve-month use of mental health services in the United States: Results from the National Comorbidity Survey Replication. Archives of General Psychiatry, 62(6), 629-640.

Whitebird, R. R., Solberg, L. I., Jaeckels, N.A., Pietruszewski, P. B., Hadzic, S., Unützer, J., [. . .] Rubenstein, L. V. (2014). Effective implementation of collaborative care for depression: What is needed? American Journal of Managed Care, 20, 699-707. 